\title{
Assessing the Legal English Skills of Italian Lawyers in a Perspective of Lifelong Learning - The EFLIT End-of-course Exam and University Testing: An Attempt to Cater for Real World Needs
}

\author{
By Anila R. Scott-Monkhouse*
}

In 2006 the Law Faculty of Parma University (Italy) launched EFLIT (English for Law and International Transactions), a postgraduate training project for professionals in the fields of Law and Economics aimed to improve both their language and legal skills by combining a linguistic (i.e. English for Law) and a content focus (i.e. Law in English). Since then EFLIT has developed into a national project and obtained recognition by professional associations for accreditation purposes in continuous education. This has called for a valid, reliable, standardised end-of-course test which assesses the level reached by participants and is "authentic," i.e. reflects their real needs for English and translates their competence into actual performance. The EFLIT teaching staff carried out a survey in order to identify the participants' specific requirements, and design an exam suitable for both lawyers and accountants and tailored to the needs of professionals working in Italy. The present study outlines the new format of the exam based on the results of the survey, in an attempt to bring together language assessment principles and the participants' professional needs, and compares it to the university's internal test to verify to what extent the latter matches the requirements of the students' future profession.

\section{The EFLIT Project}

In 2006 the Law Faculty of Parma University, in cooperation with the Language Centre launched EFLIT, ${ }^{1}$ a project for professionals in the fields of law (lawyers, judges, prosecutors, trainees, paralegals), and of business and finance (chartered accountants, tax advisors, financial consultants) which combines a focus on language (i.e. English for Law, at B2 level of the CEFR ${ }^{2}$ ) and content (i.e. Law in English), and a "learn-by-doing" methodology (Task-Based Learning 3 ). Having developed into a national project with courses in many different cities, it is now the largest provider of skills-based training in Legal and Business English in Italy, and holds partnerships with Bar Associations, academic institutions (including Translegal ${ }^{4}$ and ECCLE ${ }^{5}$ ), major law firms (e.g. Cleary Gottlieb Milan

* Teacher of English, University of Parma, Italy.

1. English for Law and International Transactions, accessed April 23, 2016, goo.gl/0978U7.

2. Council of Europe, The Common European Framework of Reference for languages: learning, teaching, assessment, accessed January 8, 2017, goo.gl/SseicH.

3. Jane Willis, A Framework for Task-Based Learning (Essex: Longman, 1996).

4. Europe's leading firm of lawyer-linguists, accessed April 23, 2016, goo.gl/GLiqk. 
and Withers London), institutions involved in continuous education in the legal sector (e.g. Consorzio Uniforma ${ }^{6}$ ), and associations of legal and business professionals (e.g. AIGA, the Italian Young Lawyers' Association ${ }^{7}$ ), which have recognised all EFLIT programmes for accreditation purposes in the continuous education of Italian lawyers and accountants. The sessions are entirely in English, and the teaching material includes authentic professional documents, both adapted and unabridged (e.g. contracts, balance sheets, memos). The staff is made up of linguists who work on English for Specific Purposes (ESP), university lecturers, visiting professors, ${ }^{8}$ professionals with international experience and guest speakers. ${ }^{9}$

EFLIT currently comprises a Premium programme (covering 48 hours in 4 months), and a Classic programme (consisting of 18 hours divided into 6 seminars), in addition to customised programmes for firms, advanced sessions, an active mailing list for alumni, and a newsletter. It also offers a database including 200 legal documents and templates, a translation of legal documents, consultancy and assistance to graduates seeking admission to LLM Masters' programmes abroad, and study visits to the Temple University Beasley School of Law (Philadelphia, USA), to law firms and court houses in London, and to Worcester College in Oxford (UK) within the ECCLE "International Legal and Business Practice" programme. EFLIT focuses on the needs of the contemporary world's "always-on" mode with weekly contributions in the Legal \& Business English section in Euroconference News, ${ }^{10}$ YouTube videoclips and an updated Facebook group page. ${ }^{11}$ Moreover, thanks to its LinkedIn community and pages ${ }^{12}$ (a Higher education page, and a company page) it implements the EU recommendations from the Annex on Key Competences for Lifelong Learning (2006), ${ }^{13}$ in particular "digital literacy," which includes managing online identity

5. European Centre for Continuing Legal Education, accessed April 23, 2016, goo.gl/vWFWtW.

6. Consorzio Uniforma, accessed April 19, 2016, goo.gl/o0A1f4.

7. Associazione Italiana Giovani Avvocati, accessed April 23, 2016, goo.gl/31DTE0.

8. David Sohenshein from the Temple University Beasley School of Law (Philadelphia, USA, goo.gl/TsFOF, accessed October 11, 2014) is a regular visitor.

9. Beatrice Collier, barrister at Middle Temple, London (goo.gl/KEJRyH) is a regular visitor, and the British Consul in Milan and the general counsel of the European Food Safety Authority (EFSA, goo.gl/ccH6I) were invited speakers in the 2010-2011 edition, whilst researchers specialising at the UN International Crime and Justice Research Centre (goo.gl/vj3tH) gave a talk in the 2015-2016 edition (accessed January 13, 2017).

10. Euroconference News, accessed April 23, 2016, goo.gl/8Ckv3k.

11. Facebook, accessed April 23, 2016, goo.gl/avpeCq.

12. EFLIT community LinkedIn pages, both accessed December 29, 2016, goo.gl/K5U2Se \& goo.gl/hedGPz.

13. European Parliament, Council of the European Union, Recommendation of the European Parliament and of the Council of 18 December 2006 on key competences for lifelong 
and reputation. Finally, it has an active social programme, with dinners, legal movie nights, and an annual White Party to bring together contemporary and past participants from different parts of Italy while raising money for charity. ${ }^{14}$

The present study concentrates on the Premium course, which awards participants a university certificate on passing an end-of-course exam, and consists of three modules:

- Legal English,

- Business English,

- Law and Business classes (covering topics such as professional correspondence, contracts, corporate law, financial statements, ethics and professional conduct) led by university lecturers, scholars and experts.

"The purpose of any ESP curriculum [...] is to meet the specific linguistic and pragmatic needs of students as they prepare for identified English-medium contexts"15 since "The ultimate proof for an ESP course is how well learners can fare when using English in the target situation; after the course they should be more effective and more confident."16 Participants themselves have claimed to be generally more interested in improving their English than actually gaining credits in the continuous learning programme, as their main aim is to be able to "use English in real life situations" [quote] because they realise that "Global business speaks English."17 The course in itself is a "stepping stone" towards developing autonomy and building confidence so that participants can operate effectively and independently in their field. The objective is to help them overcome the restricted competence of only being able to do what has been specifically practised in class as the risk in any ESP course, where class-time is limited, is to become too narrowly focused on teaching fixed phrases and behaviours, rather than strategies enabling learners to adapt to new situations. ${ }^{18}$ Participants need to be able to use English confidently and manage in less

learning (2006/962/EC), Official Journal of the European Union L 394/10 of 30.12.2006, accessed April 23, 2016, goo.gl/S1BKBc.

14. In partnership with the association Ho avuto Sete to implement life-improvement projects in Africa, accessed January 8, 2017, goo.gl/AIv1Ki.

15. Anna M. Johns, and Donna Price-Machado, "English for Specific Purposes: Tailoring Courses to Student Needs - and to the Outside World," in Teaching English as a Second or Foreign Language, ed. Marianne Celce-Murcia (Boston MA.: Heinle \& Heinle Thomson Learning, 2001), [3rd edn.], 48.

16. Tony Dudley-Evans, and Maggie St John, Developments in English for Specific Purposes (Cambridge: Cambridge University Press, 1998), 210.

17. Tsedal Neeley, "Global Business Speaks English," Harvard Business Review (from the May 2012 issue), accessed April 25, 2016, goo.gl/Y8DLTw.

18. Henry Widdowson, Learning Purpose and Language Use (Oxford: Oxford University Press, 1983). 
predictable situations in the real world, and given the limited time busy professionals can devote to English outside the classroom, it is essential to add an element of learner training (i.e. becoming aware of what being a (language) learner actually means and developing skills in "learning how to learn") in a perspective of lifelong learning, ${ }^{19}$ as also recommended by the aforementioned Annex. An explanation of what is being done (including the "how" and "why") helps develop the learners' confidence as it equips them with the necessary tools to continue working alone; ${ }^{20}$ the aim is to encourage reflection and heighten their consciousness of the learning process ${ }^{21}$ so that they are sensitized to it, ${ }^{22}$ acquire coping skills by transferring skills to non-prespecified situations, and are consequently empowered. ${ }^{23}$

\section{The EFLIT Exam}

From its first edition the EFLIT Premium programme has ended with an exam prepared, administered and marked by the language teachers to assess the level reached by participants upon completing the course. However, as DudleyEvans and St John ${ }^{24}$ explained,

The reasons for assessment can be grouped under two main headings: for feedback to aid learning and for a comparable measure of competence. [...] Assessment as an aid to learning encompasses benefits such as reinforcement, confidence building, involvement and building on strengths.

19. David Nunan, The Learner-Centred Curriculum (Cambridge: Cambridge University Press, 1988a).

20. Willis, A Framework for Task-Based Learning.

21. As the Organisation for Economic Cooperation and Development states in its proposal for the PISA 2018 Global Competence assessment, "An essential element of modern learning is the ability to reflect on the way one learns best" (OECD, Global Competency for an Inclusive World, accessed January 22, 2017, goo.gl/CbqUdl.

22. David Little, "We're all in it together: exploring the interdependence of teacher and learner autonomy," in All Together Now, ed. Leena Karlsson, Felicity Kjisik and Joan Nordlund (Helsinki: University of Helsinki Language Centre, 2000).

23. This was further developed in Anila R. Scott-Monkhouse, "Creating a profile for Italian users of legal English in a perspective of lifelong learning. The EFLIT experience," in Právní jazyk: od teorie k praxi - Legal Language: from Theory to Practice, ed. Renata Vystrčilová (Olomouc: Palacky University, Faculty of Law, 2013); Anila R. ScottMonkhouse, "The EFLIT participant: customising the course to the needs of legal English users in Italy," in European Projects in University Language Centres, ed. Carmen Argondizzo (Bern: Peter Lang, 2015).

24. Dudley-Evans, and St John, Developments in English for Specific Purposes, 210. 
By using integrative rather than discrete point testing this exam aims to test proficiency rather than achievement, ${ }^{25}$ i.e. have predictive validity of the participants' future performance by using contextualised language rather than testing their progress, as the specificity of language for professional purposes lies in the learners' actual needs to use the language in specific communication situations. ${ }^{26}$ Past papers of exams such as ILEC ${ }^{27}$ and ToLES Advanced ${ }^{28}$ appeared to be too difficult for EFLITers, and this led to the devising of a test based on existing exams for task types and skills to be tested, but tailored to both the participants and the EFLIT course regarding the level and contents. The EFLIT exam currently comprises of five components: Use of English (i.e. lexis, grammar and functions), Reading, Listening, Writing and Speaking, each carrying $20 \%$ of the total weight. The single components are further subdivided into:

a) Use of English: multiple choice gapped sentences testing grammar and vocabulary; sentence transformation (informal to formal register); matching words to definitions;

b) Reading: two law-related texts (text with true/false comprehension questions; gapped text with removed sentences to be inserted);

c) Listening: two law-related recordings in order to complete gapped notes;

d) Writing: a message to a colleague based on a prompt;

e) Speaking: providing personal and professional information and discussing a legal topic.

The criteria used in the sections requiring subjective marking are based on the CEFR. In particular, the criteria used for the writing section are: task achievement, format, register and style, logical sequencing and cohesion, grammatical and lexical range and accuracy, spelling and punctuation, whilst the

25. Jean Jimenez, and Daniela Rizzuti, "An investigation into the factors affecting the content and design of achievement tests," in Testing in University Language Centres, ed. Maria Grazia Sindoni (Soveria Mannelli: Rubettino Editore, 2008).

26. Olena P. Petrashchuk, "Testing Languages for Specific Purposes," in Proceedings for the NAU 2010, 3, accessed February 25, 2017, goo.gl/S4j00P.

27. The International Legal English Certificate is an examination pitched at a B2/C1 level of English produced and assessed by the English Language Assessment Examinations board of Cambridge University in collaboration with Translegal and consists of four components (Reading, Listening, Writing and Speaking), accessed January 9, 2017, goo.gl/x3B6yd.

28. The Test of Legal English Skills (accessed April 23, 2016, goo.gl/ACRRN5) is a series of vocational exams offered at three levels of increasing difficulty (Foundation, Higher, Advanced) which are intended to assist practising professionals in their use of "commercial" legal English rather than academic legal English. They are issued by Global Legal English, who are members of the International Division of the Law Society of England and Wales. 
criteria for the speaking section are: fluency, interactive communication and discourse management, grammar and vocabulary (range and accuracy), and pronunciation..$^{29}$

Participants have defined the EFLIT exam as "more challenging than expected," as "There wasn't enough time to carry out all the tasks or at least do them carefully" and "The "listening" was very difficult, they spoke too fast." However, they generally judged the Speaking section as "motivating, fun, gratifying." Despite their gloomy impressions, the overall average score was a satisfactory $71 \%$ (with $86 \%$ in the Reading Section, $73 \%$ in Speaking, $70 \%$ in Listening, 67\% in Use of English, and 61\% in Writing).

\section{EFLITers Experience ILEC Pre-Testing}

From the start participants have been encouraged to aim for the ILEC, mainly because the result is "tangible," also the certificate is internationally recognised and can be linked to the European Language Portfolio. ILEC is specifically designed for law students and practising lawyers, and aims to assess the candidates' ability to operate in English "in an international legal setting" 30 it is reliable thanks to the standardisation of texts, tasks and examiners through regular piloting and coordination sessions, and its criteria are reasonably clear for the test-takers. Some of the most confident participants have taken the ILEC pre-test, a "mock-exam" in which Cambridge English Language Assessment trials materials in order to ensure that they are appropriate, accurate, reliable and fair. Pre-testing allows potential candidates to test their skills in the paper-based sections of the ILEC with genuine questions under exam conditions. They are given the scores for the Reading and Listening papers, and receive feedback on their performance in the Writing test as it is marked by authentic ILEC examiners. This helps students identify which areas require more practice, and gives them experience and confidence in taking tests. ${ }^{31}$ The Parma University Language Centre is a recognised Cambridge Assessment "live" centre and the pre-test has been administered several times since 2007. Only $2 \%$ of the total number of EFLITers have taken the pre-test, and have been extremely satisfied with the whole experience, but the results have not been very encouraging. Here too candidates complained of the "frenzied timing," difficulty of the tasks and complexity of the texts (in both the Reading and Listening sections). The overall average score was $51 \%$ (56\% in the Reading section, $45 \%$ in Listening, and $52 \%$ in Writing, with vocabulary, structure and language mostly judged as

29. Andy Baxter, Evaluating your Students (London: Richmond Publishing, 1997).

30. University of Cambridge - ESOL Examinations, Cambridge English Legal International Legal English Certificate (ILEC) - CEFR Levels B2-C1: Handbook for Teachers, accessed February 25, 2017, goo.gl/FXXvm2.

31. goo.gl/kE1TJF, accessed February 25, 2017. 
"satisfactory"). ${ }^{32}$ However, rather than being a reason for discouragement, this has had a positive washforward effect as it has turned out to be a good indicator of what has been achieved, and what needs attention and remedial work. ${ }^{33}$ Timemanagement appears to be a major issue in both tests, perhaps due to previous experiences in taking tests, ${ }^{34}$ as examinees in Italy are usually granted more time: the written exams taken by high school leavers to obtain their final qualification lasts four to six hours on average, and the exam for admission to the bar lasts eight hours. Moreover, candidates are not allowed a dictionary in the Pre-test or ILEC, whilst they can consult reference texts (e.g. dictionaries) in school tests and the codes during the bar exam. Among the different factors affecting performance, there are therefore even psychological and practical reasons related to the candidates' rather disappointing results, with time being their greatest enemy and outcomes related to not having suitable exam strategies, growing anxiety and frustration, and fear of losing face. The need for a valid, reliable, relevant, accurate, practical and standardised test has emerged, to assess the level reached at the end of the course without influencing the teaching/learning process (i.e. teaching/learning "to the test"), ${ }^{35}$ and translate competence into performance in the real world without discouraging candidates, i.e. a test which looks at future use of language rather than what has been learned in the course as a result of teaching. ${ }^{36}$ This test is to be perceived as a reflection of goals reached, competencies acquired, and deficiencies to be remedied in the process of lifelong learning, yet also relevant to the participants' needs and connected to the context they operate in Porcelli. ${ }^{37}$ This need is all the more felt now as ILEC has been discontinued with the final sessions held in December 2016, and the only alternatives provided being Cambridge English Advanced, a C1 level exam of general English, or Business Higher, a test of advanced professional English which, however, does not assess ability to operate in a legal context.

32. For an analysis and comparison of the exams and related results, see: Anila R. Scott-Monkhouse, "Assessing the language skills of legal English learners through internal and external testing. The experience of EFLIT candidates," in Innovation in Methodology and Practice in Language Learning - Experiences and Proposals for University Language Centres, ed. Christopher Williams (Newcastle-upon-Tyne: Cambridge Scholars Publishing, 2015).

33. David Gardner, and Lindsay Miller, Establishing Self-Access: from Theory to Practice (Cambridge: Cambridge University Press, 1999).

34. Barry O'Sullivan, Notes on Assessing Speaking 2008, accessed April 23, 2016, goo.gl/NXNdMq.

35. Serafina Filice, and Marilyn Pasqua, "Reaching CampusOne objectives: from "specific" competence to certification," in Testing in University Language Centres, ed. Maria Grazia Sindoni (Soveria Mannelli: Rubettino Editore, 2008).

36. Jimenez, and Rizzuti, "An investigation into the factors affecting the content.

37. Gianfranco Porcelli, Educazione linguistica e valutazione (Language Education and Assessment) (Padova: Editrice Liviana, 1992 \& Torino: UTET Libreria, 1999), [2nd edn.], accessed April 23, 2016, goo.gl/j1llJK. 


\section{The EFLIT Participant Profile}

In order to design a suitable test, it was necessary to identify requirements and expectations to be taken into account and define an EFLIT participant profile through detailed needs analysis. ${ }^{38,39}$ Indeed, "One of the purposes of $[\ldots]$ needs analysis is to involve learners and teachers in exchanging information so that the agendas of the teacher and the learner may be more closely aligned."40

In 2011 an electronic questionnaire was devised and uploaded on the University Language Centre website, ${ }^{41}$ and the link emailed to both contemporary participants and alumni in order to obtain a contemporary and follow-up feedback. ${ }^{42}$ The questions were simple and direct (one-click answers) and written in Italian to avoid misunderstandings which might be caused by unfamiliar meta-language and to ensure rapidity, as time is a major constraint on busy professionals. ${ }^{43}$ However, a final open-ended question allowed interviewees to provide any feedback they wished to express. ${ }^{44}$ Both the results of the survey and the comments were taken into account in defining the profile, as was any information which spontaneously came out in informal talks during coffee breaks or social events. ${ }^{45}$ The questionnaire highlighted that participants mainly use English to

- read contracts, professional correspondence, journal articles;

- write contracts and professional correspondence;

- listen to conference talks and seminars;

- speak in meetings and discussions, and for small talk.

They rate listening skills as the most important ones in their profession, followed by writing, speaking and reading, with vocabulary being more relevant than grammar. They want to improve specific terminology, listening comprehension, reading comprehension and sentence structure, and need, yet have difficulty in speaking and writing (i.e. productive skills). ${ }^{46}$ It should be

38. Baxter, Evaluating your Students.

39. Liz Tudball, "Is English a Key employability skill?," Pearson English (blog), December 7, 2015, goo.gl/yqsYTA, mapped language skills across job roles, and Lindsay Oishi, "How to meet the needs of global professionals," Pearson English (blog), February 12, 2016, goo.gl/NphR2M, presented a flipped classroom model for working professionals.

40. David Nunan, Syllabus Design (Oxford: Oxford University Press, 1988b), 79.

41. goo.gl/5YRl1a, accessed April 23, 2016.

42. R. R. Jordan, English for Academic Purposes: A Guide and Resource Book for Teachers (Cambridge: Cambridge University Press, 1997).

43. Dudley-Evans, and St John, Developments in English for Specific Purposes.

44. See Appendix A for an English version of the survey.

45. Dudley-Evans, and St John, Developments in English for Specific Purposes.

46. See Appendix B for a summary of the most relevant results from the survey. 
noted that what is intended by "speaking" is not simply oral production, but oral interaction (i.e. processing, understanding and responding to spoken input), which necessarily includes "active listening," 47 i.e. the vital skill needed in authentic spoken interactions which involves paying attention to both verbal and non-verbal clues, managing the topic, turn-taking, questioning, reformulating, and generally building up a relationship. ${ }^{48}$

\section{The Revised EFLIT Exam}

On the basis of the results, a new EFLIT exam is being devised to assess the candidates' competences in the macro-skills defined by the Council of Europe (i.e. reading comprehension, listening comprehension, written production, oral production and interaction) by adapting the content and tasks, and the weighting of the components to the candidates' professional role in an attempt to blend immediate and long-term needs within a lifelong learning perspective. ${ }^{49}$ The test aims to be representative of the real-life situations which lawyers and accountants can expect to encounter, and to allow examiners to make reliable inferences on the candidate's ability to manage them. Although the format recalls Cambridge Assessment exams, it aims to be a proficiency test of ESP which differentiates itself from international certificates whose contents, level, standards and criteria are too high and too general for Italian professionals.

The first main difference lies in the weighting of the components to reflect the participants' actual needs: Listening 29\%, Writing 26\%, Speaking 24\%, and Reading $21 \%$, and tasks within each section are to be assigned different weighting too. The Use-of-English section is to become part of the Writing and Reading sections, ${ }^{50}$ granting greater weight to vocabulary than grammar. The criteria for components requiring subjective marking are defined according to the CEFR and with reference to internationally recognised certificates following the indications of ALTE. ${ }^{51}$

47. Dudley-Evans, and St John, Developments in English for Specific Purposes.

48. Norbert Schmitt, An Introduction to Applied Linguistics (London: Hodder Arnold, 2002).

49. The initial idea was triggered by a similar project previously devised for primary school teachers of English in Italy and discussed in Anila R. Scott-Monkhouse, "Towards a standardised qualification for primary school teachers of English as a foreign language. The experience of Parma (Italy)," Language Learning in Higher Education 2, no. 1 (2013).

50. This corresponds to the structure of ILEC and is also in line with similar changes brought about by Cambridge English Language Assessment to their First and Advanced exams in 2015, accessed January 2, 2017, goo.gl/1XthMQ.

51. Association of Language Testers in Europe, accessed April 23, 2016, goo.gl/YQEeMo. 
Candidates will be allowed to use monolingual dictionaries in order to replicate both previous exam experiences and real-life situations (where they can, if not must consult reference materials), lower levels of anxiety, test their dictionary skills, and further test their ability to manage both the resources and time available. The Reading section is to consist of four tasks based on lawrelated texts, i.e.:

a) a multiple choice cloze text with a higher number of questions testing vocabulary than grammar; 52

b) a text with multiple matching questions (i.e. matching one-sentence summary headings to paragraphs); 53

c) a gapped text with sentences to be re-inserted by referring to linkers and connectors;

d) a text with multiple choice comprehension questions to test understanding of specific lexis and phrases by referring to context, and a word formation table to be first filled in starting from words in the text and then used as a reference to complete a summary cloze test. ${ }^{54}$

The Listening section is to include three tasks, i.e. listening to:

a) a conversation between a professional and a client while re-arranging

b) summary sentences;

c) a conversation between two colleagues while completing a simple text (e.g. diary page);

d) a mini-lecture while completing notes. .55

The Writing section is to include a "controlled written component" comprising four "in-class" tasks:

a) correction of sentences containing mistakes commonly made by Italian learners of (legal) English;

b) completion of a contract or professional letter using standard phrases/sentences;

52. Maria Grazia Sindoni, "Testing English at University. Some reflections on validation," in Testing in University Language Centres, ed. Maria Grazia Sindoni (Soveria Mannelli: Rubettino Editore, 2008).

53. Assunta Caruso, "Designing an achievement test for University students: a look at validity and reliability," in Testing in University Language Centres, ed. Maria Grazia Sindoni (Soveria Mannelli: Rubettino Editore, 2008).

54. Sindoni, "Testing English at University.; \& Caruso, "Designing an achievement test for University students.

55. Dudley-Evans, and St John, Developments in English for Specific Purposes. 
c) redrafting of sentences from informal to formal register, or from "legalese" to modern plain English;;

d) a 100-word communicative text written in response to a prompt providing input, purpose and specification of recipient, i.e. an integrated task (reading and writing) which corresponds to most real-life situations as a "study- and work-related writing is written for a readership, for a purpose, and about a specific matter;" 57

and a "home" assignment consisting in,

e) a 350-word composition which is either the presentation of their professional profile/firm to a foreign colleague/client (factual/ descriptive writing), or an opinion essay (critical/analytical writing) on a current topic (e.g. a law reform, a contemporary debate in professional practice in Italy). This corresponds to the length of a standard abstract and allows the candidates to prove their skills through an extended composition in a less threatening situation, without the pressure of exam timing and conditions. Adherence to the number of words and a high level of accuracy are expected as they can use a variety of resources (including computer spell-checking and word-count functions), and have time to draft, edit and revise..$^{58}$

The Speaking section still requires further adjustments. What is to be assessed is the candidate's ability to interact with the examiner, talk about topics of personal and professional interest, develop ideas, support opinions, explain, hypothesise, paraphrase, and link sentences together. $.9,60$ Errors, repetitions and hesitations should not affect understanding and fluency, i.e. the speaker should not put too much strain on the listener. ${ }^{61}$ This section is to include three parts, i.e.: 62

56. Sensitivity to register is also highlighted in ToLES Advanced, accessed January 22, 2017, goo.g1/UxERcf. For the campaign in favour of plain English see Peter M. Tiersma, The Plain English Movement, accessed January 22, 2017, goo.gl/nejuL3.

57. Dudley-Evans, and St John, Developments in English for Specific Purposes, 225.

58. This is largely based on the Portfolio writing tasks section of Trinity College London ISE IV exam, accessed January 2, 2017, goo.gl/k2537v.

59. O'Sullivan, Notes on Assessing Speaking 2008.

60. Council of Europe, Relating Language Examinations to the Common European Framework of Reference for Languages: Learning, Teaching, Assessment (CEFR). A Manual (Strasbourg: Language Policy Division, 2009), accessed January 8, 2017, goo.gl/HGVa7U.

61. As also required by Cambridge English Language Assessment in the Speaking component of exams. This is assessed under Discourse Management/ Interactive Communication in their Main Suite exams (University of Cambridge ESOL Examinations, Research and Validation Group, Examples of Speaking Performance at CEFR Levels A2 to C2 (Cambridge: University of Cambridge, 2009), 13-14, accessed 
a) an ice-breaking activity with the candidate providing personal and professional information;

b) a role play with the candidate answering and asking questions ${ }^{63}$ in a simulation with high interactive authenticity based on a role assigned by the examiner;

c) the discussion of a previously chosen professional issue with the candidate presenting information and arguments, expressing opinions and giving reasons.

This new version of the EFLIT test is currently being tried out as a whole and the project is still ongoing.

\section{University Testing and Real World Needs: Do They Meet?}

The results of the survey are an interesting starting point for further reflection on whether university language education and professional needs actually meet. This unfortunately does not appear to be the case at present at the University of Parma. Law students take a compulsory 90-minute computerized test of general English at B1 level which consists in multiple choice randomized questions in tasks focusing on the Use of English (i.e. grammar and lexis with greater focus on grammar, accounting for $44 \%$ of the test), Reading and Listening (weighting equivalent to $29 \%$ and $27 \%$ respectively). There is no Speaking component due to lack of resources (i.e. time and number of examiners in relation to the number of students). The choice of this format, which is largely based on the Cambridge English Language Assessment Preliminary exam, ${ }^{64}$ is due to:

- its practicality, as it is easy to administer and to mark consistently and rapidly;

- its objectivity, transparency and reliability;

- its versatility, as the same test can be recycled for students of other degree courses;

January 8, 2017, goo.gl/S4BnnT), and under Fluency and Coherence in IELTS (i.e. the International English Language Testing System, which "measures the language proficiency of people who want to study or work where English is used as a language of communication," accessed January 8, 2017, goo.gl/5P6hcl \& goo.gl/5X4Q21).

62. Dudley-Evans, and St John, Developments in English for Specific Purposes.

63. Ibid.

64. Cambridge English Language Assessment Preliminary, accessed May 13, 2016, goo.gl/Afam0X. 
- the fact that it gives students a greater chance to pass the exam (listening is notoriously known as the most difficult section, and Italian students tend to perform better in grammar and reading due to previous learning experience). ${ }^{65}$

The single components are further subdivided into:

a) Use of English: cloze text testing grammar more than vocabulary; sentences containing grammatical mistakes to be identified; gapped sentences testing grammar;

b) Reading: comprehension of short texts (emails, labels, notices, etc.), of an adapted authentic factual text, and of an adapted authentic text to understand the author's attitude, opinion and purpose;

c) Listening: comprehension of key information in short conversations, of a factual monologue (e.g. tour guide), and of a dialogue to understand attitudes and opinions.

If we were to cater for the students' future professional needs and respect validity criteria, i.e. establish a link between the educational setting and professional requirements, the level, weighting, texts and topics (if not tasks) would have to be changed so that the test is relevant to the students' present situation and future socio-professional context. At the same time, as the internal assessment within the degree course is an achievement rather than a proficiency test, it should constitute a threshold of performance in a blend of educational and professional needs with the skills and structures to be tested specified within a syllabus in order to create the basis for "a principled selection of elements for inclusion in the test." Yet, as this is hopefully just one of the stages in their learning English ${ }^{66}$ (and education in general), the test itself should encourage the students to develop their own personal techniques for autonomous learning, an essential skill in their academic and future professional life.

One of the main problems in implementing such a change is that English classes and the exam itself are often perceived as being less important than other subjects, mainly because the exam is on a pass/fail basis and therefore does not

65. Computerised language testing in university is a currently debated topic in Italy, and advantages and disadvantages were discussed by Anila R. ScottMonkhouse in her talk "La quadratura del cerchio: valutazione di abilità linguistiche e test informatizzato. Dov'è il nostro П?" [Squaring the Circle: Language Skills Assessment and Computerised Testing. Where is our П?] in the round table at the conference on Searching for Good Practices in Language Teaching and Skills Testing on the European Day of Languages, Department of Language and Cultural Studies, University of Modena, Italy, September 26, 2016.

66. Caruso, "Designing an achievement test for University students:, 39. 
affect the final grade. Consequently, commitment and motivation are low and, as English classes often overlap with other mandatory classes, attendance to English classes is often low too. On the other hand, if the exams were seen as matching their interests and reflecting their future professional needs, there most probably would be a corresponding positive change in the students' attitude.

Another problem lies in the large number of candidates, leading to mixed-ability classes due to the non-homogeneity of their level of and skills in English, which affect how individual needs can be dealt with and in general render a learner-centered approach difficult to implement. In the Italian university system students are entitled to at least three exam window periods per academic year and are allowed to take any exam they may fail countless times within the duration of their degree course, so many students end up by repeatedly sitting the exam of English as, due to all of the reasons outlined above, there is an unfortunate tendency on their behalf of trying to "attempt" the test in the hope of passing, which leads to a rather high fail rate and a constantly high number of examinees per session. ${ }^{67}$

Finally, the internal resources available are limited. This applies to the budget, but also to the number of teachers/examiners who are simultaneously involved on several degree courses, the time needed to plan and teach lessons, and also to organize, administer and invigilate overcrowded tests, and to the pressure they are under to offer further exam dates.

A solution might be a compromise between ideal and feasible, with an internal exam which maintains the characteristics of the present test (i.e. multiple choice, unchanged weighting of components) so as not to lose the advantages it offers, but uses adapted law-related texts and topics. This would obviously have an impact on the teaching, with a new syllabus to be devised and lesson planning changed in order to allow for a more field-specific scope. As this demands time of the teachers, students would need to become more responsible for their learning with more independent self-study required, at least as far as the basics of general English are concerned, and a B1 level would have to be a prerequisite. Consequently elements of learner training would have to be included in language classes, which would reflect positively on the students' academic performance in general by encouraging learner autonomy, one of the objectives of university instruction and of lifelong learning projects. Any changes would clearly have to be gradual to allow both examiners and examinees to adapt, so that the objective could be more easily reached.

67. In order to try to overcome this problem, the Language Centre's laboratory advisors provide more student-centred support to the examinees who have proven to struggle the most by offering autonomy-inspired guided learning paths (Micol Beseghi, and Greta Bertolotti, "Designing tailor-made academic paths for university language students," Language Learning in Higher Education 2, no. 2 (2012): 319-337. 


\section{Conclusions}

Today's world individuals are required to establish their credentials by proving their abilities, and the EFLIT exam aims to be a recognised assessment tool with face, content and construct validity by being criteria-referenced and utilising adapted authentic tasks and materials which reflect proficiency rather than achievement in order to reliably predict the professionals' future performance. The revised test differentiates itself from others in that it addresses language for specific purposes while taking into account the context in which the candidates are to work, i.e. the requirements of their profession in Italy. The use of texts, tasks and strategies which resemble the candidates' real life uses of the language not only stimulates their motivation, ${ }^{68}$ but also responds to the need for a standardised test with tasks that mirror the activities which the candidates are called to carry out within their job, and that allows for the assessment of their skills in relation to both legal language and professional needs. Given the constraints of the exam setting and format, and the level reached by the participants, it may not be a true measure of their language competence in real world contexts, but a valid indication of how they can cope. It is to be considered both a point of arrival and a starting point, i.e. a tool for the assessment of professionals to attest the level of English reached, and a step towards autonomy in the improvement of their language skills in a perspective of lifelong learning, pursuant to the specific requirements of the legal profession. For this reason it is essential that the test yields positive results in terms of both washback and washforward effects, as the objective is to define a legal professional who is a competent and confident user of English with a view to further professional development. As Gardner and Miller ${ }^{69}$ put it, "Assessments provide an opportunity for reflection. They can help learners gain a clearer picture of their abilities, encourage reflection on learning and provide evidence of their achievements." Ultimately, this would be the aim of both the EFLIT and the internal university test.

68. Arthur Hughes, Testing for Language Teachers (Cambridge: Cambridge University Press, 2003), [2nd edn.].

69. Gardner, and Miller, Establishing Self-Access: from Theory to Practice, 222. 


\section{Appendix A}

\section{An English version of the survey}

\section{EFLIT Needs Analysis Survey}

1) I am a(n)

- lawyer

- notary

- magistrate

- in-house lawyer

- trainee lawyer

- doctoral student

- undergraduate (please specify: Law, Economics, Political Sciences)

- accountant

- trainee accountant

- other (please specify)

\section{2) I am interested in/deal with}

[tick max 3]

- criminal law

- international law

- family law

- administrative law

- labour law

- tax law

- company law

- mergers and acquisitions (M\&A)

- contracts

- finance and auditing

- other (please specify)

3) As far as English is concerned, in my job the different language skills rank as follows

[assign a score from 1 to 10; assign 1 to the skill(s) you consider to be the least important and 10 to the skill(s) you consider to be the most important; the same score may be assigned more than once if you feel one or more skills are equally important]

\begin{tabular}{|l|l|l|l|l|l|l|l|l|l|l|}
\hline & 1 & 2 & 3 & 4 & 5 & 6 & 7 & 8 & 9 & 10 \\
\hline Reading & & & & & & & & & & \\
\hline Listening & & & & & & & & & & \\
\hline Speaking & & & & & & & & & & \\
\hline Writing & & & & & & & & & & \\
\hline Grammar & & & & & & & & & & \\
\hline Vocabulary & & & & & & & & & & \\
\hline Pronunciation & & & & & & & & & & \\
\hline
\end{tabular}


4) I use English

with [tick all relevant ones]

- foreign clients

- foreign colleagues

- lecturers

- members of networks/associations I belong to

- other (please specify)

to [tick all relevant ones]

- read correspondence from colleagues/clients, etc.

- read professional journals/websites

- read contracts and other legal/financial documents (e.g. balance sheets, wills, summons, tenders, etc.)

- read regulations and/or judgements

- read and assess résumés and cover letters

- write to colleagues/clients (emails, letters, faxes, etc.)

- write articles for professional journals

- draw up contracts and other legal/financial documents (e.g. balance sheets, wills, summons, tenders, etc.)

- write legal opinions

- write résumés and cover letters

- attend conferences/seminars/workshops (and take notes)

- discuss with colleagues

- explain legal opinions and possible legal actions to clients

- attend professional meetings

- make phone calls, conference calls, etc.

- give talks at conferences

- small talk

- other (please specify)

5) My previous experience of learning English was

- at school (what school? how long?)

- in private courses (what kind? what level?)

- abroad (what programme? e.g. Erasmus, doctorate, etc.)

- other (please specify)

6) I have studied for/obtained an international English language certificate

- none

- Cambridge English Preliminary

- Cambridge English First

- Cambridge English Advanced

- Cambridge English Proficiency

- Trinity ISE (what level? ................)

- Trinity GESE (what level? ................) 
- TOEFL IbT (score obtained ...........)

- IELTS (score obtained ...........)

- BEC (what level? ................)

- TOLES (what level? ................)

- other (please specify)................

7) I chose EFLIT to [tick max 3]

- improve my professional image

- meet my job's/my employer's requirements, etc.

- be able to communicate with foreign colleagues/clients

- keep up to date in my profession

- not feel left out by the requirements of contemporary society

- have greater professional opportunities (e.g. promotion, career moves, etc.)

- overcome the difficulty of finding legal translators/interpreters

- pursue my personal interest

- other (please specify)

8) Outside the course I can dedicate this amount of time to learning English

- one hour a day

- one evening a week

- the weekend

- other (please specify)

9) In order to consolidate what I have learned I mainly intend to [tick max 3]

- revise/tidy up my notes

- do some listening practice

- watch movies

- use the Internet

- use past papers from international certificates (e.g. ILEC / ICFE / BEC)

- do grammar practice

- read the textbook

- read articles and websites on topics I am interested in

- talk to foreign friends/colleagues

- other (please specify)

10) Through EFLIT I expect/hope to [tick max 3]

- achieve a good understanding of professional written English

- achieve a good understanding of professional spoken English

- become fluent in spoken English

- be able to write my own professional correspondence

- become independent of the dictionary

- other (please specify) 
11) With EFLIT I would like to [tick max 3]

- improve my grammar

- increase my law/economics/finance-related vocabulary

- learn to use a monolingual dictionary/glossary

- be given suggestions on how to improve my learning

- learn to move from informal to formal register

- discuss professional topics of common interest

- carry out communicative activities (e.g. pair/group work, simulations, roleplay, etc.)

- write letters and emails

- read professional texts

- listen to law-related audio material

- watch law-related video material

- other (please specify)

I would like to focus on the following grammar and lexis [tick max 3]

- sentence structure

- use of conjunctions (e.g. although, so that, etc.)

- use of prepositions (e.g. comply with, subject to, etc.)

- modal verbs (e.g. may, shall, etc.)

- if-clauses (e.g. If you wish to attend, interpreting will be provided, ...)

- passive voice (e.g. Payment was not received, ...)

- collocations (e.g. legal assistance, draft a contract, etc.)

- word formation (e.g. oblige - obligation - obligatory)

- other (please specify)

12) In the course I would rather NOT

- focus on grammar

- focus on pronunciation

- dedicate time to reading

- dedicate time to writing

- focus on vocabulary

- other (please specify) 


\section{Self-assessment}

Assign a score from 10 (max) to 1 ( $\mathrm{min}$ ), for each entry in the table below with $10=$ absolutely true and $1=$ absolutely false

I have difficulty with

\begin{tabular}{|l|l|l|l|l|l|l|l|l|l|l|}
\hline & 1 & 2 & 3 & 4 & 5 & 6 & 7 & 8 & 9 & 10 \\
\hline Reading & & & & & & & & & & \\
\hline Listening & & & & & & & & & & \\
\hline Speaking & & & & & & & & & & \\
\hline Writing & & & & & & & & & & \\
\hline Grammar & & & & & & & & & & \\
\hline Vocabulary & & & & & & & & & & \\
\hline Pronunciation & & & & & & & & & & \\
\hline
\end{tabular}

I like

\begin{tabular}{|l|l|l|l|l|l|l|l|l|l|l|}
\hline & 1 & 2 & 3 & 4 & 5 & 6 & 7 & 8 & 9 & 10 \\
\hline Reading & & & & & & & & & & \\
\hline Listening & & & & & & & & & & \\
\hline Speaking & & & & & & & & & & \\
\hline Writing & & & & & & & & & & \\
\hline Grammar & & & & & & & & & & \\
\hline Vocabulary & & & & & & & & & & \\
\hline Pronunciation & & & & & & & & & & \\
\hline
\end{tabular}

I need

\begin{tabular}{|l|l|l|l|l|l|l|l|l|l|l|}
\hline & 1 & 2 & 3 & 4 & 5 & 6 & 7 & 8 & 9 & 10 \\
\hline Reading & & & & & & & & & & \\
\hline Listening & & & & & & & & & & \\
\hline Speaking & & & & & & & & & & \\
\hline Writing & & & & & & & & & & \\
\hline Grammar & & & & & & & & & & \\
\hline Vocabulary & & & & & & & & & \\
\hline Pronunciation & & & & & & & & & & \\
\hline
\end{tabular}

Further comments and/or suggestions (e.g. I have never found a course which ..., etc.) 


\section{Appendix B}

\section{A summary of the most relevant results from the survey ${ }^{70}$}

Table 1. Ranking of average scores assigned to each individual skill in response to question 3

\begin{tabular}{|l|c|}
\hline Listening & 8 \\
\hline Vocabulary & 7.7 \\
\hline Writing & 7.6 \\
\hline Speaking & 7.4 \\
\hline Reading & 7.2 \\
\hline Grammar & 7.2 \\
\hline Pronunciation & 6.5 \\
\hline
\end{tabular}

This result shows the perceived importance of each macro-skill in relation to professional needs.

Table 2. Most frequent answers to question 4 on the participants' use of English in relation to the language macro-skills

\begin{tabular}{|l|c|c|c|c|}
\hline & Reading & Writing & Listening & Speaking \\
\hline $\begin{array}{l}\text { Contracts and Legal/Financial } \\
\text { Documents }\end{array}$ & $88 \%$ & $62 \%$ & & \\
\hline Professional Correspondence & $87 \%$ & $88 \%$ & & \\
\hline Professional Journals/Websites & $94 \%$ & & & \\
\hline $\begin{array}{l}\text { Conference Talks, Seminars, } \\
\text { Workshops }\end{array}$ & & $(61 \%)$ & $61 \%$ & \\
\hline Professional Meetings & & $(62 \%)$ & $(62 \%)$ & $62 \%$ \\
\hline Discussions & & & $(62 \%)$ & $62 \%$ \\
\hline Small Talk & & & $(60 \%)$ & $60 \%$ \\
\hline
\end{tabular}

Only percentages above $60 \%$ were taken into account. The figures in brackets refer to "indirect" percentages, i.e. sub-skills involved in the activity (e.g. taking notes while attending conferences and meetings, listening to the speaker in discussions in order to respond, etc.).

70. A more detailed analysis can be found in Anila R. Scott-Monkhouse, "Towards a standardized certification of English as a foreign language for Italian professionals practicing in the legal sector," in Explorations in Language and Law - Language and Law in Academic and Professional Settings: Analyses and Applications, ed. Vijay K. Bhatia, Giuliana Garzone, Rita Salvi, Girolamo Tessuto, and Christopher Williams (Aprilia: NovaLogos, 2014). 
Table 3. Most frequent answers to questions 9 and 10 combined on the participants' expectations

\begin{tabular}{|l|l|}
\hline Increase Law/Finance-Related Vocabulary & $89 \%$ \\
\hline Achieve a Good Understanding of Professional Spoken English & $79 \%$ \\
\hline Achieve a Good Understanding of Professional Written English & $68 \%$ \\
\hline Improve Sentence Structure in Written English & $62 \%$ \\
\hline
\end{tabular}

Only percentages above $60 \%$ were taken into account.

Table 4. Average scores assigned to each individual macro-skill in self-assessment

\begin{tabular}{|l|c|c|}
\hline & Find Difficult & Need \\
\hline Reading & 4.2 & 6.7 \\
\hline Listening & 7.6 & 8.2 \\
\hline Speaking & 8.3 & 7.4 \\
\hline Writing & 7.9 & 7.7 \\
\hline Grammar & 4.9 & 5.9 \\
\hline Vocabulary & 6.1 & 7.8 \\
\hline Pronunciation & 4.7 & 6.2 \\
\hline
\end{tabular}




\section{Bibliography}

Baxter, Andy. Evaluating your Students. London: Richmond Publishing, 1997.

Beseghi, Micol, and Bertolotti, Greta. "Designing tailor-made academic paths for university language students." Language Learning in Higher Education 2, no. 2 (2012): 319-337.

Caruso, Assunta. "Designing an achievement test for University students: a look at validity and reliability." In Testing in University Language Centres, edited by Maria Grazia Sindoni, 37-48. Soveria Mannelli: Rubettino Editore, 2008.

Council of Europe. Relating Language Examinations to the Common European Framework of Reference for Languages: Learning, Teaching, Assessment (CEFR). A Manual. Strasbourg: Language Policy Division, 2009. Accessed January 8, 2017. goo.gl/HGVa7U.

Council of Europe. The Common European Framework of Reference for languages: learning, teaching, assessment. Accessed January 8, 2017. goo.gl/ SseicH.

Dudley-Evans, Tony, and St John, Maggie. Developments in English for Specific Purposes. Cambridge: Cambridge University Press, 1998.

European Parliament, Council of the European Union. Recommendation of the European Parliament and of the Council of 18 December 2006 on key competences for lifelong learning (2006/962/EC). Official Journal of the European Union L 394/10 of 30.12.2006. Accessed April 23, 2016. goo.gl/S1BKBc.

Filice, Serafina, and Pasqua, Marilyn. "Reaching CampusOne objectives: from "specific" competence to certification." In Testing in University Language Centres, edited by Maria Grazia Sindoni, 65-82. Soveria Mannelli: Rubettino Editore, 2008.

Gardner, David, and Miller, Lindsay. Establishing Self-Access: from Theory to Practice. Cambridge: Cambridge University Press, 1999.

Hughes, Arthur. Testing for Language Teachers. Cambridge: Cambridge University Press, 2003, [2nd edn.].

Jimenez, Jean, and Rizzuti, Daniela. "An investigation into the factors affecting the content and design of achievement tests." In Testing in University Language Centres, edited by Maria Grazia Sindoni, 83-100. Soveria Mannelli: Rubettino Editore, 2008.

Johns, Anna M., and Price-Machado, Donna. "English for Specific Purposes: Tailoring Courses to Student Needs - and to the Outside World." In Teaching English as a Second or Foreign Language, edited by Marianne Celce-Murcia, 4354. Boston MA.: Heinle \& Heinle Thomson Learning, 2001), [3 $3^{\text {rd }}$ edn.].

Jordan, R. R. English for Academic Purposes: A Guide and Resource Book for Teachers. Cambridge: Cambridge University Press, 1997.

Little, David. "We're all in it together: exploring the interdependence of teacher and learner autonomy." In All Together Now, edited by Leena Karlsson, 
Felicity Kjisik and Joan Nordlund, 45-56. Helsinki: University of Helsinki Language Centre, 2000.

Neeley, Tsedal. "Global Business Speaks English." Harvard Business Review (from the May 2012 issue). Accessed April 25, 2016. goo.gl/Y8DLTw.

Nunan, David. The Learner-Centred Curriculum. Cambridge: Cambridge University Press, 1988 a.

Nunan, David. Syllabus Design. Oxford: Oxford University Press, 1988b.

OECD. Global Competency for an Inclusive World. Accessed January 22, 2017. goo.gl/CbqUdl.

Oishi, Lindsay. "How to meet the needs of global professionals." Pearson English (blog). February 12, 2016. goo.gl/NphR2M.

O'Sullivan, Barry. Notes on Assessing Speaking 2008. Accessed April 23, 2016. goo.gl/NXNdMq.

Petrashchuk, Olena P. "Testing Languages for Specific Purpose." In Proceedings for the NAU 2010, 3, 149-155. Accessed February 25, 2017. goo.gl/S4j00P.

Porcelli, Gianfranco. Educazione linguistica e valutazione (Language Education and Assessment). Padova: Editrice Liviana, 1992 \& Torino: UTET Libreria, 1999, [2nd edn.]. Accessed April 23, 2016. goo.gl/jlllJK.

Schmitt, Norbert. An Introduction to Applied Linguistics. London: Hodder Arnold, 2002.

Scott-Monkhouse, Anila R. "Towards a standardized certification of English as a foreign language for Italian professionals practicing in the legal sector." In Explorations in Language and Law - Language and Law in Academic and Professional Settings: Analyses and Applications, edited by Vijay K. Bhatia, Giuliana Garzone, Rita Salvi, Girolamo Tessuto, and Christopher Williams, 287-300. Aprilia: NovaLogos, 2014.

Scott-Monkhouse, Anila R. "Creating a profile for Italian users of legal English in a perspective of lifelong learning. The EFLIT experience." In Právní jazyk: od teorie $k$ praxi (Legal Language: from Theory to Practice), edited by Renata Vystrčilová, 209-216. Olomouc: Palacky University, Faculty of Law, 2013.

Scott-Monkhouse, Anila R. "The EFLIT participant: customising the course to the needs of legal English users in Italy." In European Projects in University Language Centres, edited by Carmen Argondizzo, 189-208. Bern: Peter Lang, 2015.

Scott-Monkhouse, Anila R. "Assessing the language skills of legal English learners through internal and external testing. The experience of EFLIT candidates." In Innovation in Methodology and Practice in Language Learning - Experiences and Proposals for University Language Centres, edited by Christopher Williams, 230247. Newcastle-upon-Tyne: Cambridge Scholars Publishing, 2015. 
Scott-Monkhouse, Anila R. "Towards a standardised qualification for primary school teachers of English as a foreign language. The experience of Parma (Italy)." Language Learning in Higher Education 2, no. 1 (2013): 227-243.

Sindoni, Maria Grazia. "Testing English at University. Some reflections on validation." In Testing in University Language Centres, edited by Maria Grazia Sindoni, 139-151. Soveria Mannelli: Rubettino Editore, 2008.

Tiersma, Peter M. The Plain English Movement. Accessed January 22, 2017. goo.gl/nejuL3.

Tudball, Liz. "Is English a Key employability skill?." Pearson English (blog). December 7, 2015. goo.gl/yqsYTA.

University of Cambridge - ESOL Examinations. Cambridge English Legal International Legal English Certificate (ILEC) - CEFR Levels B2-C1: Handbook for Teachers. Accessed February 25, 2017. goo.gl/FXXvm2.

University of Cambridge - ESOL Examinations, Research and Validation Group. Examples of Speaking Performance at CEFR Levels A2 to C2. Cambridge: University of Cambridge, 2009. Accessed January 8, 2017. goo.gl/S4BnnT.

Willis, Jane. A Framework for Task-Based Learning. Essex: Longman, 1996.

Widdowson, Henry. Learning Purpose and Language Use. Oxford: Oxford University Press, 1983. 
